\title{
Early Khasi Response to Christian Missions: Challenges, Acceptance and Assertion.
}

\author{
Magdalyne Syiemlieh \\ Department of History, St.Mary's College, Shillong, India.
}

\begin{abstract}
Christian missions came to the Khasis of Meghalaya early in the 19th century, independent of the colonial policy but in many ways facilitated by the new political and administrative developments. The first mission among the tribe was the English Baptist Mission of Serampore. This was followed by the Welsh Calvinistic Methodist Mission which commenced its activities in 1841. Though the Catholics had been in the region much earlier their formal activity of mission commended in 1890.

This paper makes an attempt to study three aspects of the history of Christianity in the region and in particular among the Khasis, one of the first of the tribes who encountered and engaged with Christian mission. It studies the early history of the establishment of the missions, and the challenges the missionaries encountered and the response both reactionary and acceptance of the faith among sections of the tribe. The growth is registered and the main activities of the churches are highlighted. The paper concludes with the assertion of the tribe, the establishment of the Seng Khasi and the profession of the Christian faith among the tribe.
\end{abstract}

Keywords: Christian missions in the Khasi Hills, English Baptist Mission of Serampore, Seng Khasi, Christian Schools in the Khasi Hills, Catholic mission in the Khasi Hills.

\section{Introduction}

The history of Christianity in North-East India in the $19^{\text {th }}$ and $20^{\text {th }}$ centuries is closely related to colonial expansion and the political and administrative developments following the Anglo-Burmese War and the signing of the Treaty of Yandaboo 1826. After the annexation of Assam by the British in 1826 the entire region was brought either under direct or indirect administration of the British and placed under the larger Indian political system. This in turn brought an end to the isolation of the region and introduced new elements in its political, economic, social and cultural composition.

\section{Baptist Mission}

The Charter Act of 1813, opened the protestant missionaries to preach the gospel in India and the Serampore Baptist Mission, a branch of the London Baptist Society was the first to arrive in the Khasi Hills. The arrival of William Carey, a Baptist missionary from England in Calcutta on $11^{\text {th }}$ November 1793 marked the beginning of active Christian Mission work in North-East India. In 1818, Carey founded the Serampore College in Bengal - to train Indians for missionary work. After seven years of his stay in Bengal, he was able to baptize the first Hindu convert name Krishna Chandra Pal on $28^{\text {th }}$ December 1800 , who also became the first missionary among the Khasis. Thus Pal's conversion may be taken as the starting point of the study of the advent of Christianity among the Khasis.

It was in early 1813, that Judge L.N. Garret of Sylhet, nephew of Robert Raikes, founder of the 'Sunday School' in England wrote and suggested to Carey that he should seek to convert the Khasis to Christianity. On his suggestion, Carey sent Krishna Pal who arrived at Sylhet on March $20^{\text {th }} 1813$. On $7^{\text {th }}$ April, he proceeded to Pandua which lies at the foot of the Khasi Hills below Cherrapunji. Pandua then, was a very important trading centre and a meeting place of the Khasis and Bengalis. It belonged, in those days to the Khasi hima (State) of Cherrapunji although it was in the plains. Pal's efforts of preaching met with success as he himself wrote:

"The Judge wished me to visit the country of the Khasis, and gave me introductory letters to the Jemadar, and a native sepoy for protection. The Jamadar entertained me very kindly, I had many opportunities of making known the Gospel there; and I have great hopes that four sepoys, two natives of Khasis, and one of Assam were brought to believe in the Lord Jesus. A few days after, Mr. Smith and the other two gentlemen of the station arrived there, and having called the seven individuals, enquired whether they believed in the death of Christ, and that he suffered for sinners and were willing to be baptized in his name. On their replying to all these questions in the 
affirmative, they desired me to give them Christian baptism..... We went down to the Dlebolisshore river, there we present eight native chiefs, and about 600 natives of Khasia. I read and expounded a chapter of scriptures, and after prayer, baptized the seven candidates."

After remaining at Pandua for eight months, Krishna Pal returned to Serampore and though the work which he had commenced in the new district was not entirely neglected, yet the fair promise made at its commencement was not fulfilled. Persecution followed and it is this that the new converts could not bear. Though it was suggested that the name of the two Khasi converts was U Duwan and U Anna, they probably did not remain active Christians which is an early indication of the challenges before the missionaries.

Though the early mission to the Khasis was short lived, it did lead to the inclusion of Khasi as one of the many languages into which Serampore translated the scriptures. By late 1813, Carey secured the services of a Pandit for the purpose of translation and a limited edition of 500copies of the New Testament in the Bengali script was brought out in 1824 and distributed to the Khasis who lived in Sylhet and who could read the Bengali script. However, the translation was so imperfect as to be quite unintelligible to the Khasis and a new translation was later on undertaken by the Welsh Presbyterian missionaries when they started work in 1841, using the Roman script.

After Pal's departure in 1829, Carey sent a young Scotsman James Rae, who had served for some years in the East India Company's artillery, to work in Gauhati. It was hoped that he could reach the Khasis, Garos, the Manipuris and other tribes from there. In his first report in 1830, Rae mentioned that he had twelve interesting youths-three Khasis and nine Garos under his care sent by David Scott, Commissioner of Assam. Two of whom appeared to be heirs of Rajas of Khasi himas (States) and the other appeared to be the brother of Tirot Sing Syiem (chief) of Nongkhlaw. But the plan to fully reach the Khasi community with the Gospel did not materialize and no converts were reported. Rae remained in Gauhati till 1836.

A third attempt was made by the Baptist mission when Alexander B. Lish only 18 years old, was sent to operate from Cherrapunji. The Headquarter of the British government of the Khasi Hills, during that period was Cherrapunji. With the help of a Khasi scholar U Laithat, Lish opened three schools, at Sohra, Mawsmai and Mawmluh. The school at Cherrapunji, initially made great progress with an average daily attendance being thirty-six but slowly dwindled. Lish's efforts to evangelize the Khasis did not apparently meet with any possible success, except that two of his pupils U Duwan Rai and U Jungkha served as language pundits for the first Presbyterian missionary Thomas Jones. Lish found the Khasi people so steeped in ignorance as to make it almost impossible to convert any religious ideas to them. In his words:

"The only religion understood by them consisted in endeavouring to appease the demons with sacrifices of goats, fowls, sheep and pigs"

Towards the end of 1837, the Serampore mission was amalgamated with the Baptist Missionary society and the work in the Khasi Hills was abandoned. Lish, himself returned to Calcutta as he was suffering and passed away at an early age of 38 in 1852 .

\section{Welsh Calvinistic Methodist Mission}

After the Baptist abandoned the area following a hesitant and unsuccessful start, Rev. Jacob Tomlin came to Cherrapunji in 1840, on a chance visit during a journey to China. After his stay in the Khasi hills for nine months, he reported his findings back home recommending commencement of evangelical work. By then, the London Missionary Society, an orthodox society had suffered a split and the Welsh group that separated had formed its own mission - the Welsh Calvinistic Methodist Mission (later to become the Welsh Presbyterian) and though it was low on resources, the deficiency was more or less made up by the high sense of devotion, zeal and commitment of its workers. On the recommendation of Jacob Tomlin, the Welsh mission sent its first missionaries Rev Thomas Jones and his wife who finally arrived at Cherrapunji on $22^{\text {nd }}$ June 1841.

By 1843, the residence of the Thomas Jones was shifted from Cherrapunji to Nongsawlia hill, midway between the cantonment and the village. It was here, that the first Khasi converts of the Welsh mission U Amor and U Rujon were baptized on $8^{\text {th }}$ March 1846. Though nothing is said about the precise date on which the Nongsawlia church which was the first church in the North-Eastern hills, was organized, it never the less marked its beginning as a Khasi church. According to Natrajan:

"The arrival of these missionaries must have been welcomed by the

British forces in Cherrapunji, for the British military administration apparently felt that the best way to tame the primitive and wild Khasis was through love, which the missionary alone could give".

By early 1842 , Jones decided to open three schools at Mawsmai, Mawmluh and Cherrapunji. At the same time, he gathered a number of youths for instructions in the mission house. The first teachers for the schools were selected from among the young men, for Jones felt that the people needed to be educated and then only, could the process of evangelization start as the people lived under the influence of fear, superstition, 
ignorance and, sluggishness. In order to feel the pulse, Jones accompanied by Captain Lewis visited the area south of Cherrapunji where the Wars (one of the group belonging to the Khasi tribe) live and also visited a market place in the Jaintia Hills; one year later, Jowai turned out to be one of the main mission stations in Jaintia Hills.

Eighteen months after the arrival of the Jones, they were joined by Reverend and Mrs. William Lewis and Dr. Owen Richards. Reverend and Mrs. Lewis undertook a few translations which were to serve as texts in schools. For his preparation of the First Khasi Reader (Ka Kot Pule Banyngkong), a translation of the Welsh Catechism and 'Rhodd Mam' or Mother's Gift into Khasi and its publication in 1842, may rightly be regarded as the beginning of Khasi literature. Natrajan writes:

"Jones decided to adopt, the Roman alphabet to Khasi, giving it a phonetic structure by reassigning the sounds represented by various letters...... Thus in a gentle and steady manner, new windows to the vistas of knowledge in the world around were opened to the Khasis..............Jones thus became the father of Khasi literature".

However, due to his differences with the Mission Directors of Liverpool, Jones was forced to leave his mission. This was followed some years later with Jones leaving the hills, infected with malaria; he passed away at Calcutta on $16^{\text {th }}$ September 1849 . His departure indeed deprived the Khasis of a committed missionary. Among many appreciative words on the man we may refer to Ben Rees:

"People flocked from afar to see the white man............. Who could do everything as well as telling them about God. Indeed as they looked at his many talents- speaking the language teaching the children and the adults in the method and techniques of the Welsh Sunday School, turning his hands to carpentry, masonry-many of them felt that Thomas Jones was like God, able to do everything".

\section{Challenges}

Although the Welsh Mission, had laid the foundations for the strategy to reach the Khasis with the Gospel, the year between 1841 to 1845 , could be said to be 'fruitless years' in the sense that there was not a single person baptized during the period. It was only on $8^{\text {th }}$ March 1846, that two Khasis U Amor and U Rujon were baptized. This was followed by Ka Nabon in 1848 (the first Khasi female convert) and later Ka Bir and Ka Phuh were also baptized. In 1850, the first Christian marriage in the Khasi Hills was solemnized when ka Phuh married U Luh, another convert. One of the main reasons for the slow pace of proselytisation was due to the high standard of church membership expected of converts. B.C Allen, Superintendent of the Census operations believed:
"The chief proselytizing agency in the province is the Welsh Mission whose efforts in the Khasi and Jaintia Hills have been extraordinary successful..... Amongst them (Khasis) however, as amongst the other hill tribes, the stricter standard of morality is a stumbling block.... If the missionaries were able to relax their moral code, the numbers of their converts would in all probability be largely increased".
The early challenges faced by the missionaries are best explained by Frederick S. Downs:
"In fact the initial opposition was often greater and more violent among hillmen then it was among Hindus and Moslems.....But for the protection offered by the British government, the Christian movement in the Northeastern hills would have a much longer list of martyrs, including missionary martyrs, than it does now".

Frederick. S. Downs a renowned church historian lauded the courage shown by a few individuals, who decided to become Christians in the face of strong social and physical pressure when they had very little to gain materially and very much to lose by becoming Christians.

Among them were a number of converts belonging to the families of the Syiems (chiefs). Several gave up even Syiemship (chieftainship) in order to become or remain Christian. One such case was that of U Borsing, who was heir to the Syiemship of Cherra. Six months after Borsing's conversion, the Syiem died and U Borsing was acknowledged by the village elders to be the rightful successor, but cannot become Syiem without first 'renouncing' Christianity to which he refused. His nephew was selected in his place. Borsing not only lost the Syiemship but all of his personal property was also confiscated.

Another case worth taking note of was the conversion and baptism of Ka Nabon, the first Khasi woman convert, who had to flee to the mission house for fear of her Kur (clan) and friends alike. The mission house was surrounded by hostile crowds, threatening violence and in all probability it would have been burnt down had it 
not been stopped by the intervention of the British army. On her death in 1857 , her family members wanted to cremate her but despite the quarrel and a minor civil revolt, she was finally buried.

Persecution of the female converts continued to be most violent as is evident from one of the letters written by Mr. Lewis while referring to the case of a female scholar named ka Chot, who lived with them in the mission compound and who had suffered greatly at the hands of her family, who even took up her case of conversion with the Syiem (chief). One of the reasons that may be attributed to the persecution of women converts being that the Khasis who had taken counsel of the village "diviners" or "egg breakers" in matter of female education believed that every female who touched a book could be childless, and thus the clan would become extinct. Superstitions and prejudices of the people were in fact far more deeply rooted than what the missionaries had believed. Morris wrote of this:

"Breaking of eggs and other means of consultation with the demons were resorted to daily .Children were often instructed not to pay any heed to the teacher nor their lessons, least the wroth of the demons overtake them and their clan be destroyed".

For those who do not fear either threats nor violence and continued to go to school persecution followed in which clothes were stripped open or beaten cruelly. Further, a belief among the Khasis that some families and clan keep in their house a kind of demon or spirit known as "U Thlen" to whom human blood was offered or sacrificed and in return the devil, blesses the family with wealth. The Jaintia belief in 'Taro,' another kind of demon which involved a number of rituals to get rid of it and in which the Bengali pundits frequently profited for performing the rituals posed serious problems to the missionaries.

Often the direct interference of the missionaries in the religious rites, beliefs and practices of the people led to tension in Khasi- Jaintia society. The Khasis believe that illness, misfortunes etc arise out of transgression of man's duties which cause a divide between God and man and such transgressions are remedied through sacrifice, rituals and asking for forgiveness from God. Preservation of forests as sacred grooves had been practiced by the Khasis since times immemorial. They are mostly governed by their belief systems in conserving these forests and which are generally set aside for religious purposes. The missionaries however, wanted the people to believe that their belief in the sanctity of the sacred grooves was a silly superstition of unlettered people believing that gods or evil dwell in them and that no harm would befell them if they disregarded such senseless sanctions. Regarding the harvest festival Rev. Jerman Jones himself asserted:

"Harvest feast were not seemly for those who have learned to read the word of God. It was quite convinced that such feast were altogether unworthy of professed Christians and that an end must be put to them at once".

The fact that the church itself initiated the practice of giving stipends to students who were likely to return to their villages for church works or as school teachers (since the converts have been trained in theology) created a deep wedge among the people. Those who lived in the so called special compounds considered themselves more advanced and literate then those residing in the original villages or in other words, the heathens. The Jaintias were infuriated by the fact that the converts often decried their own religion and taunted the others to give up their traditional pujas. No wonder when the Jaintia uprising occurred between 1860 and 1863, it led to an attack on the Presbyterian Mission stationed at Jowai and even Christian settlements were not spared which prompted the British authority to shift some converts towards Cherrapunjee for security reasons.

A much more deeply rooted cause for the slow pace of proselytisation in the $19^{\text {th }}$ century may be traced to the abandonment of the Bengali script and the introduction of the Roman script which was strongly resented by the Khasis at the initial stage. At Shella which was then a fairly Hinduised village, owing to contact with the Bengalis of Sylhet, the people even made attempts to burn down the missionary school. The Khasis felt no initiative to send their children to school, where Bengali had no room, while the Jaintias even considered it as an attack on their tradition. Hence the lack of response to education between the years 1841-1860 may be ascribed to the replacement of the Bengali script by the Roman script, a point which was emphasized by William Robinson, the Inspector of Schools in an article published in the Calcutta Review. He even pleaded for the retention of the Bengali script in the Khasi and Jaintia hills on grounds of commercial relations of the Khasis with the people of the plains.

While commenting on the slow pace of education in Welsh Mission Schools, Hudson, the Principal Assistant Commissioner felt in 1858 that:

"These schools would have met with less opposition and greater success, had instruction been given in the Bengali language, and even

had the Bengali instead of the Roman characters been used in writing the Cossyah language".

In the light of the above comments, it must be understood that the Bengali language which enjoyed a special status in the southern Khasi and Jaintia hills, since it formed a link between the Khasi chiefs and their 
subjects in the plains was uprooted by the Roman character. Secondly, many Syiems (chiefs), like the Syiem of Sohra, Ganga Sing, was a Bengali Cosseah, possessing territory in the hills and also held many parganas in Sylhet formerly subject to the Mughal Court. Moreover, many who were offered the Syiemship were Bengali Muslims from Sylhet, thus originated the Khasi state of Mawiang with Bartap Khan, Puna Khan, Jubor Khan etc as Syiems. Although, these rulers had adopted Khasi customs and the Khasi way of life, they could not however, remain immune from the influence of the language and culture of which they had originally been the products.

\section{Acceptance}

Though the first conversion must have posed many psychological problems and barriers, nevertheless the church made a gradual but definite progress in the Khasi hills by laying emphasis on education and healthcare. By the end of 1849, the number of Christians stood at twenty one. In 1853, a church was established at Shella and in 1854, a school in Jowai and by 1856, Christianity had acquired a foot hold in other areas of Jaintia hills. Churches were established in the West Khasi Hills in 1860-61 and by 1875 the Bhoi area also saw the advent of Christian Missionaries.

Establishment of schools were facilitated by the order of the then Governor General of India Lord Dalhousie, who had instructed the government to extend help to the missionaries in 1854 and an amount of Rupees fifty was sanctioned monthly to the missionaries as grants to further its educational work. After the suppression of the Jaintia Rebellion in 1863, Colonel Haughton who was so impressed by the fact that the Christians in Jaintia hills did not join the rebels, urged upon the government, that the grant to the mission should be increased and consequently the Grant in Aid was raised to Rupees five hundred. Lack of qualified teachers however, continued to hamper the missionaries work. One way out, was the conversion of the Nongsawlia School to a Normal Training School in 1864, which was transferred to Shillong in 1867 and back to Cherra in 1891, where it became a separate department in Cherra Theological College.

A significant change in the early period which contributed to the growth of the church in the Khasi hills was the acceptance and conversion of members of the Syiem's families. Among them, Kine Singh, the Syiem of Khadsawphra became a convert only after a referendum brought to vote 10 to 1 for conversion before his subjects. Eventually, he was made a deacon of the Mairang Church and later given the title of 'Raja' by the British in recognition of his good and honest way of ruling his area. The Sidar of Mawden by the name of K.Liar, also became a convert after which Rev. Griffith Hughes, succeeded in making Mawden village, an 'entirely Christian one' and built a church there. According to the Natrajan:

"The Syiem of Mawden issued a proclamation in consonance with the

teachings of the missionaries, that nobody should drink liquor".

By 1866 there were 60 churches, 65 day schools and 307 Christians. The year 1869 saw the emergence of indigenous ministry through the beginning of evangelist examination which institute procedure to test the abilities of evangelists to serve as pastors. In the same year, a printing press, the first of its kind in the Khasi Hills was started at Cherra, which was also patronized by the government. By 1887, a Theological institution at Cherra, under John Roberts as principal started training local Khasis in evangelical work.

In 1879, Rev. Griffith opened a dispensary at Mawphlang which marked the beginning of medical work. The year also witnessed a severe plague which swept the hills in which hundreds of people died. Rev. Jerman Jones and other Christians rendered selfless sacrifice to minister to the sick and the dying, when their own relatives forsook them. Non-Christians were moved by the missionary's love and concern for the sick and the dying and could not but come to believe in Christ and join his church. To quote Becker:

"The fame of the so called "medical mission" (among the Khasis

during a cholera epidemic) served to open up many villages to the

gospel and prepared the way to further mission work."

By 1890, four native evangelists named Juramon Lyngdoh, U Lang Laloo, U Sanbin Gatphoh and U Ksan Shella were ordained as the first Khasi pastors. The year 1895, saw the establishments of 5 Presbyteries:Sohra- Shella Presbytery; Shillong- Mawlai; Mawphlang- Mairang; Jowai- Shangpung and the Ri Dkhar (plains) and its first annual meeting met at Shella in 1896 with Rev Evans as chairman and a native pastor Amrikha as first Secretary. While making a reference to the first of the Khasi pastors Morris stated:

"The rapid advancement made during the last fifteen or twenty years

(1871-1891) are doubtless to be attributed to the extensive employment of native helpers".

Beginning with 1846, when Jones printed the Gospel of St Mathew, 1853, Rev William Lewis published a revised translation of Mark, Luke and the Book of the Acts of the Apostles. By 1871, the whole of the New Testament was published and twenty years later in 1891- saw the complete translation of the Bible under Rev and Mrs John Roberts along with a number of Khasi elders.

The fruit of the sacrifice of the home and native churches for over half a century was however, very seriously affected by the great earthquake of 1897 . However, though many thought that this was the end of the 
mission and the church, the earthquake did not affect the faith of the converts, rather the numbers increased. As in the plague of 1879, the calmness, peace and assurance which the Christians displayed to the non-Christians in the face of death drew a large number of converts to its church. By 1899 the number of Christians rose to 14,215 against 6,862 in 1891. 2,372 new converts were baptized in 1897 alone.

\section{Catholic Mission}

There were small numbers of Europeans and some Anglo Indians who lived and worked in Assam and its hills. They came into the region to make their fortune in the mines, tea gardens and the railways. Their religious needs however, were hardly attended to by the handful of Missionaries in far away Bengal. Although the entire Northeast India was under the jurisdiction of the Vicar Apostolic of Calcutta since its establishment in 1834, the Vicariate never had sufficient personnel to spare for the pastoral ministry of its small flock scattered in and around Assam.

After many serious searches for a solution for neglected Assam, Pope Pius IX through a decree dated $28^{\text {th }}$ June 1870 erected as new Prefecture Apostolic of central Bengal with Krishnagar as Prefecture HQ to which the territories of Assam and Bhutan would be adjoined. Mgr. Marietti was appointed the Prefect Apostolic of the Prefecture and the region was entrusted to the Milan Foreign Mission (PIME) which had been founded since 1850 to undertake missionary activities in foreign countries and who were already active in Krishnagar since 1855.

In 1872, PIME superiors sent Fr. Jacobi Broi to Assam to be resident missionary. By 1887, the Bishops of Northern India met at Allahabad and proposed that a Prefecture Apostolic be created in the North East with territories curved out of Krishnagar and Dhaka Vicariates. On $13^{\text {th }}$ Dec, 1889 Pope Leo XIII established the Prefecture Apostolic of Assam, Bhutan and Manipur, comprising the Brahmaputra valley, Surma valley (Cachar and Sylhet districts), and the Hill Districts, with the exception of Mizoram- still part of Dhaka Vicariate.

The new Prefecture was entrusted to the Catholic Teaching Society later to be known as the Society of Divine Savior (Salvatorians SDS) which had been recently founded on $8^{\text {th }}$ December 1881, by Fr J.B. Jordan at St Bridget, Rome. After 47 days of journey, the first missionaries under Fr. Otto Hopfenmuller, a newly ordained priest Anjelus Munzlocher, and a lay Brother Marianus Schum and Joseph Bachle, reached Shillong on $27^{\text {th }}$ Feb 1890 and with them was born the Prefecture Apostolic of Assam.

The small catholic community which existed at Shillong then numbered around twenty and was mainly Englishmen, Anglo Indians and a few catholic servants coming from other parts of India. There was not a single Khasi Catholic among them. Fr. Otto Hopfenmuller and Bro. Marianus Schum and their companions threw themselves whole heartedly into the task of mastering the Khasi language and in concentrating all their efforts in bringing the local people of Shillong to the Catholic faith. It was indeed frustrating for him to see that the Presbyterians who came from Wales had established themselves among the Khasis fifty years before their arrival and had a great number of followers, some churches and schools, and published books in the Khasi language. In one of his letter to the Superior General (Fr J.B. Jordan), Hopfenmuller opined:

"If we cannot form a community of Khasi Christians here, our stay will be useless".

In his small and unfurnished "Good Hope Villa" Fr. Hopfenmuller, dedicated himself to great zeal to learning the Khasi Language and within a few weeks he began to translate into Khasi the "Our Father" and "Hail Mary" and in preparing a text of basic Catechism and a short Bible history in Khasi. By August 1890, he reported to the Cardinal Prefect, that the Catechism was already under print at the Jesuit Press in Calcutta. Besides the translation of the Old Testament, the translation of the Life of Jesus and Blessed Virgin Mary were also underway.

Yet the very health resort of Shillong claimed the lives of the two pioneers within a few months. Fr Otto died on $22^{\text {nd }}$ August, 1890 possibly of meningitis, while Bro. Marianus followed him ten days later stricken down by dysentery.

Angelus Munzlocher, only twenty four years old had to take up the leadership of the mission as Apostolic Administrator to be associated by Bro Joseph. However, by January 1891, there came to their rescue three priests, one Brother and three Salvatorian sisters- the first ever missionary sisters in North East India. In the hills in Shillong Fr Angelus bought "Lum Tyngkong", called "Hopkinson's Wood" by the English from General Hopkinson for Rupees five thousand. This is where the present Cathedral church, Loreto convent and Don Bosco School stand. A new Mission house and a Chapel were built and by June 1891, the missionaries were able to move in.

By December 1891, a third group of three priests, and one lay Brother left Rome for Assam. By October 1892, two more priests left Rome and reached Shillong on $16^{\text {th }}$ November 1892 . By 1895 a group of four missionaries joined the Assam Mission and on $30^{\text {th }}$ January 1897 Fr. Pius Steinherr left Rome for Assam. Thus between 1890 and 1897, Fr. Jordan was able to spare nineteen missionaries to Assam. In the first period from 1890-97, the Salvatorians succeeded in establishing the major mission station of Shillong (1890), Raliang 
(1892), Shella (1895), Cherrapunjee (1897) and take over those already in existence - Gauhati (1870) and Bondashill (1800) .

Gradually, the work among the Khasis began to show results and the first Khasis were baptized on $8^{\text {th }}$ December 1891, which according to the Cathedral register were Anna Sada Nongrum and her daughter Maria Shitmon by Fr. Ignatius Bethan in St Mary's Church. A few months later on $21^{\text {st }}$ Feb 1892, Anna's son, Joseph Kynjing Nongrum was baptized in the same church. By early 1897, the number of Catholics increased to 1300 , and just when everything seemed to be optimistic, on $12^{\text {th }}$ June 1897 , the earthquake destroyed away everythingall the materials and structures of the first seven years of missionary work. Like the Presbyterians the Catholics had to restart the construction work assisted by ten to twenty catechists. According to Becker:

"These were days of great privation for the mission personnel, and

some fell ill as a result".

Though the Catholic missionaries continued to encounter serious opposition on account of blind beliefs, superstitions, sacrifices and taboos especially in convincing the womenfolk to embrace Christianity, yet the immediate problems included dearth of missionaries, return of several missionaries to their home land on account of ill health- following the fact that the region was infested with various diseases. Constant change of personnel, paucity of men and lack of sufficient means retarded both work and growth- as is evident in the case of Maram which Becker himself reported:

"In 1893, the chieftain of Rangthong came in person to Shillong to see the Mission Superior and to beg for a missionary. Under the leadership of the chieftain, a small, but very promising Christian Community was developing .............Unfortunately however the work for evangelization could not be seized for lack of missionaries".

A much more serious difficulty encountered by the Catholic missionaries was the fact that the Methodists from Wales who had started the work since 1841, considered the area their exclusive domain and fought against it in every way, a concern which the founder of the Mission, Fr. Otto Hopfenmuller himself reported on $4^{\text {th }}$ Aug, 1890 :

"They attacked the Catholics as usual in their newspaper of 5 June.

The Khasi title of the paper is 'U Nongkit Khubor'. It is imperative

that we publish a Khasi paper or at least a leaflet to answer their objection".

After the earthquake of 1897, the missionary decided to transfer the mission station from Shella to Laitkynsew, which was on top of a hill, on a ridge which offer more security. It must be noted that the ShellaLaitkynsew Mission was opened in 1893 and within two years the number of Catholics rose to 150 and the school had 70 boys and 40 girls in the first year itself. Shella however, never recovered from the earthquake and only a few villagers were able to rebuild their houses while others fled the area. It was in Laitkynsew, that the missionaries started a press whose publications served as a means towards religious instructions in the neighbouring villages, and in order to counter the unwarranted attacks of the Presbyterians against the Catholic religion, a publication under the title of 'U Nongialam Katholik' (The Catholic Leader) commenced publication.

\section{Assertion}

No doubt by the end of the $19^{\text {th }}$ century, Christianity had succeeded in making its presence into KhasiJaintia society, in spite of the initial odd, threats, persecutions and restrictions many had come to embrace the new faith.. Thus a new Christian community with its own set of values, codes and sanctions, grounded in the essential truths of the gospel and freed from the power of darkness came to light- an indication that Christianity was here to stay.

The Khasi society however, which had a definite ideology as 'closely connected beliefs or ideas or even attitudes that characterized a group or community' eventually, perceived the threat system-that many of their socio, political and cultural elements were being lost much to the detriment of their identity, slowly asserted on the Khasis. Modernization and exposure have contributed to the idea of ethnic identity and the need to assert the same for maintaining distinctiveness was felt. Here, the growth of tribal elite was a contributory factor which led Khasi elders to formulate certain methods, adopt certain measures and in some cases to launch resistance movements. The emerging Khasis Christian themselves, have in their own way offered cultural resistance by asserting that they would like to preserve their new religion at the same time keeping their pride in Khasi heritage intact by promoting certain elements in the culture which would help them to retain their Khasi identity.

The Unitarian movement in the Khasi hills was one such example- locally born, founded independently and has essentially a Unitarian outlook. The founder Hajom Kissor Sing, was born at Cherrapunjee in 1865, and through the influence of the foreign missionaries, he had converted to the Welsh Calvinistic church in his early youth. Later he began to question the rigid and sectarian teachings of the Welsh missionaries and started a new 
liberal movement called 'Ka Niam Wei Blei' (The religion which worships one God). Through his contact with the Brahmo Samaj, he established a liberal church which stood for freedom of beliefs and free expression of ideas and convictions and the love and service of all men. The movement began around 1887, with the establishment of a church at Jowai and later schools were also set up.

The above mentioned church clearly show that the Khasis who had absorbed Christianity also asserted their traditional belief within the faith. Concepts like 'faith in one God', 'Salvation through god's grace', and 'participation of all in society', which are all parts of the Khasi tradition came to be asserted.

The non Christian Khasis however, initiated resistance for asserting the Khasi culture, not in isolation but maintaining a cultural identity within a larger cultural ethos, so that the British and the missionaries could not totally subvert and undermine their cultures and also to check the subtle idea that Khasi culture was lower and inadequate in comparison to that of the British. Thus came to the forefront persons like Jeebon Roy, who initiated resistance more concretely by means of textualising Khasi oral religious and cultural traditions. He set up the first Khasi Press in 1896 and prior to which he had started a High School in 1876 in Shillong, as he felt that the people needed higher education of a secular type. In 1897, a similar High School was also set up at Shella and a Minor School was also set up at Mawkhar, Shillong in 1899, keeping Bengali in the curriculum. By 1899, with the assistance of 16 other patriotic Khasi leaders, the "Seng Khasi" a socio-cultural organization of the Khasis was founded to protect, preserve and promote the customs and traditions of the Khasi populace.

\section{Conclusion}

Thus by the end of the $19^{\text {th }}$ century, Christian Missions had managed to take firm roots in the Khasi and Jaintia hills and did so with great tenacity, patience and perseverance and under most trying circumstances. By laying emphasis on education and humanitarian services, all the three missions moved ahead in their mission to take the faith to the Khasi-Jaintias. The process of proselytizing was intensified in the $20^{\text {th }}$ century.

\section{References}

[1] Morris, J.H, The History of the Welsh Calvinistic Methodist Foreign Mission to the end of the year 1904, Carnavor, Liverpool, 1910, p.81.

[2] Ibid.

[3] Natrajan, N, The Missionary among the Khasis, sterling Publication Pvt, N.Delhi, 1977, p.63.

[4] Ibid.

[5] Rees, Ben.D (Ed) Vehicles of Grace and Hope: Welsh Missionaries in India 1800-1970, William Carey Library, 2002 , p.101.

[6] Jyrwa, J.F, The Wonderous Work of God, Ri Khasi Press, 1998, p.25.

[7] Downs, F.S, Christianity in Northeast India, ISPCK, N.Delhi; 1983, p.102.

[8] Morris, op.cit., p.97.

[9] Lamare, S.N, Resistance Movements in North East India: The Jaintia of Meghalaya 1860-1863, Regency Publication, N.Delhi, 2001, p.50.

[10] Miri, M. (Ed). Linguistic situation in North-East India, Concept Publishing Company, N.Delhi, 2003, p.42.

[11] Natrajan, opcit. p.67.

[12] Karotemprel,S.(Ed). The Catholic Church in Northeast India 1890-1915, Becker Institute, Sacred Heart Theological College, Shillong, 2007, p.239.

[13] Morris op.cit., p.195.

[14] Karotemprel,S. op.cit. p.169.

[15] Ibid, p.273.

[16] Ibid, P.283.

[17] Ibid, P.339 